\title{
Original Research \\ Assessment of Heavy Metal Contamination from Sediment and Soil in the Riparian Zone China's Three Gorges Reservoir
}

\author{
Yechun Wang, Liang Ao, Bo Lei, Sheng Zhang* \\ Chongqing Academy of Environmental Science, Chongqing 401147, China \\ Received: April 17, 2015 \\ Accepted: May 31, 2015
}

\begin{abstract}
In the Three Gorges Reservoir (TGR), sedimentation of the riparian zone has occurred over the past 10 years. However, the sediment and related environmental effects have not been explored well. In the present study, sediment and soil in situ were collected in three sites of the riparian zone in the TGR. Samples were analyzed for water content, bulk density, $\mathrm{pH}$, organic matter, total nitrogen, total phosphorus, and heavy metals (As, $\mathrm{Cr}, \mathrm{Cu}, \mathrm{Ni}, \mathrm{Pb}, \mathrm{Zn}$ ). Results revealed that, compared with soil, water content, organic matter, and total phosphorus of sediment were high while bulk density was low. Heavy metal concentrations ( $\mathrm{As}, \mathrm{Cu}, \mathrm{Pb}, \mathrm{Zn}$ ) in sediment were significantly higher than those in soil. Sediment was moderately polluted by $\mathrm{Cu}$ and $\mathrm{Pb}$, and soil was unpolluted-moderately polluted by $\mathrm{As}$ and $\mathrm{Cu}$. Moreover, the individual and comprehensive potential ecological risk of heavy metals from both sediment and soil showed a low degree. Enrichment of nutrients and heavy metals in sediment of the riparian zone are probably of formation regime and anthropogenic activities, and could pose risks to the environment and human health. Therefore, enhanced efforts of soil and water conservation and pollution treatment in the upper stream of the Yangtze River and the TGR area should be recommended.
\end{abstract}

Keywords: sediment and soil, heavy metal contamination, riparian zone, Three Gorges Reservoir

\section{Introduction}

The Three Gorges Reservoir (TGR) and dam in central China constitutes one of the largest hydropower-generation projects in the world. The reservoir has a length of $660 \mathrm{~km}$, a surface area of $1,040 \mathrm{~km}^{2}$, and a static storage capacity (water volume) of $39.3 \mathrm{~km}^{3}$ at its highest constraining water level of $175 \mathrm{~m}$ above sea level. To preserve reservoir capacity, the TGR is operated by the rule of "storing the clear water and discharging the muddy flow." Under conditions of extremely low flow, reservoir sedimentation cannot be avoided even if this operation mode is adopted. Moreover, as it stores summer flooding, the TGR will block the moving

*e-mail: shengzsts@126.com sand and cause it to pile up on the river bed as well as the riparian zone. Previous studies have estimated the sedimentation in the TGR with different approaches [1-3], and indicated that from June 2003 to December 2010 the sediment deposition was 1.17 billion tons, of which 10 million tons deposition occurred in the riparian zone [4]. In other words, sedimentation of the riparian zone occurred in the past 10 years [5]. It is worth noting that sedimentation in the reservoir results in a progressive reduction in storage capacity, and triggers a series of physical, chemical, and ecological impacts on the environment [6]. However, sediment and related environmental problems - especially in the riparian zone of the TGR - have been inadequately studied.

Heavy metals are involved in various anthropogenic activities, such as industry practices, agricultural activities, 
Table 1. Description of sampling sites in the riparian zone of the Three Gorges Reservoir.

\begin{tabular}{|c|c|c|c|c|c|}
\hline Site & Location & Aspect & Slope $\left(^{\circ}\right)$ & Vegetation & Previous land use \\
\hline S1 & $\begin{array}{c}30^{\circ} 15^{\prime} 14.41^{\prime \prime} \\
107^{\circ} 59^{\prime} 53.41^{\prime \prime}\end{array}$ & $10.1 \mathrm{NW}$ & 10.5 & $\begin{array}{c}\text { Dominated by herbs } \\
\text { with } 50 \% \text { cover }\end{array}$ & Dry land \\
\hline S2 & $\begin{array}{c}30^{\circ} 14^{\prime} 30.69^{\prime \prime} \\
108^{\circ} 00^{\prime} 04.26^{\prime \prime}\end{array}$ & $10.8 \mathrm{NW}$ & 11.3 & $\begin{array}{c}\text { Dominated by herbs } \\
\text { with } 55 \% \text { cover }\end{array}$ & Dry land \\
\hline S3 & $\begin{array}{c}30^{\circ} 13^{\prime} 52.81^{\prime \prime} \\
108^{\circ} 00^{\prime} 06.05^{\prime \prime}\end{array}$ & $8.7 \mathrm{NW}$ & 13.4 & $\begin{array}{c}\text { Dominated by herbs } \\
\text { with } 48 \% \text { cover }\end{array}$ & Dry land \\
\hline
\end{tabular}

domestic waste, and vehicles emissions, etc., and they are considered as the most serious pollutants due to persistence in the environment, bioaccumulation, and high toxicity [7, 8]. In a landscape, the riparian zone is an effective sink for heavy metals as incorporation and accumulation of pollutants from both terrestrial and aquatic systems [9]. Thus, there is an increasing concern about heavy metal contamination and related environmental effects of riparian areas in recent years [10-13]. In the TGR, previous studies showed that heavy metal pollution is present in riparian areas [14, 15]. For example, studies indicated that soil or sediment of the riparian zone was polluted by $\mathrm{Hg}, \mathrm{Cd}$, and $\mathrm{Pb}$ after submergence [16-18]. However, authors did not explore that the samples for laboratory analysis are from soil, sediment, or composite of sediment and soil in riparian areas. It is well known that the difference in formation regime between sediment and soil would have an effect on absorption, accumulation, and distribution of heavy metals. We could not obtain completely reliable information since sediment is regarded as soil, and soil is considered as sediment. In this study, therefore, the sediment was strictly separated from the soil in the riparian zone. Moreover, we hypothesized that there would be significant differences in basic physical characteristics, nutrition content, and heavy metal concentration between sediment and soil in the riparian area of the TGR. The major objectives of this study were to: 1) examine the differences in physiochemical characteristics and heavy metal concentrations between sediment and soil

2) assess the pollution status and potential ecological risk of heavy metals from sediment and soil in the riparian zone of the TGR.

\section{Materials and Methods}

\section{Site Description}

With the Three Gorges Dam fully functioning as of July 4,2012 , the water level fluctuates from $145 \mathrm{~m}$ in summer to $175 \mathrm{~m}$ in winter, resulting in the formation of the riparian zone with a total area of $344 \mathrm{~km}^{2}$ [19]. The study region is located at Zhongxian County, in the middle section of the TGR. Climate in this region is southeast sub-tropical monsoon, with an average annual temperature of $18.2^{\circ} \mathrm{C}$ and a mean annual precipitation of $1,172 \mathrm{~mm}$ [17]. Depending on altitude, vegetation in the riparian zone can be divided into two types: one is located in the low riparian zone $(145-160 \mathrm{~m})$ and dominated by perennial plants such as Cyperus rotundus and Cynodon dactylon (L.) Pers. the other is located in the high water level zone (165-175 $\mathrm{m})$, and is dominated by annual plants such as Conyza japonica (Thunb.) Less and Bidens pilosa L. [20].

\section{Sampling and Laboratory Analysis}

In this study, three typical sites with similar geological environments, vegetation, and history of land use were chosen (Table 1). Field sampling was conducted in August 2013, when the water level remained around $146 \mathrm{~m}$. Before sampling, sediment and soil were identified by comparing the vertical and horizontal compositions (color and texture) of the profiles $[5,21]$. In each site, three plots $(1 \mathrm{~m} \times 1 \mathrm{~m})$ were randomly selected for sediment and soil, respectively. In each plot, three soil or sediment samples from 0-10 cm and the 10$20 \mathrm{~cm}$ were collected with a plastic shovel, and the samples were mixed well to form a composite sample according to depth. As sedimentation mainly occurs in low altitude, such as 150-160 $\mathrm{m}$, in the riparian zone [5] all sediment samples were from this altitude. To reduce effect of elevation on characteristics of soil and sediment, soil samples were from the same area as sediment. A total of 36 composite samples, including 18 for sediment and 18 for soil, were obtained.

Soil/sediment composite samples were air-dried, passed through a $2 \mathrm{~mm}$ polyethylene sieve, and analyzed for $\mathrm{pH}$, organic matter, total nitrogen, total phosphorus, and heavy metals (As, $\mathrm{Cr}, \mathrm{Cu}, \mathrm{Ni}, \mathrm{Pb}$, and $\mathrm{Zn}$ ). $\mathrm{pH}$ was measured in a 2.5:1 ratio of water-to-soil or sediment suspension using a glass $\mathrm{pH}$ electrode [22]. Organic matter (by $\mathrm{K}_{2} \mathrm{CrO}_{7}-\mathrm{H}_{2} \mathrm{SO}_{4}$ titration method after digestion), total nitrogen (by Kjeldahl method), and total phosphorus (by molybdenum blue colorimetric method) were determined [23]. The heavy metal concentrations ( $\mathrm{As}, \mathrm{Cr}, \mathrm{Cu}, \mathrm{Ni}, \mathrm{Pb}$, and $\mathrm{Zn}$ ) were obtained by acid digestion according to Method 3050B [24]. In addition, to measure bulk density and water content, three intact soil or sediment cores were taken by core sampler when samples for heavy metals were selected, and dried at $105^{\circ} \mathrm{C}$ for $24 \mathrm{~h}$ [25].

\section{Data Analysis}

\section{Contamination Assessment}

The geo-accumulation Index $\left(I_{\text {geo }}\right)$ introduced by Müller [26] has been used widely to evaluate the degree of heavy 
Table 2. Index and grades of heavy metals pollution and potential ecological risk.

\begin{tabular}{|c|c|c|c|c|c|c|c|}
\hline Index & \multicolumn{7}{|c|}{ Grade and corresponding value } \\
\hline$I_{\text {geo }}$ & $\operatorname{UP}(\leq 0)$ & $\operatorname{UMP}(0 \sim 1)$ & $\operatorname{MP}(1 \sim 2)$ & $\operatorname{MSP}(2 \sim 3)$ & $\operatorname{SEP}(3 \sim 4)$ & $\operatorname{SP}(4 \sim 5)$ & $\operatorname{EP}(>5)$ \\
\hline$E_{i}$ & Minor $(<40)$ & Moderate $(40 \sim 80)$ & High (80 160) & Very high (160 320) & Serious $(>320)$ & & \\
\hline$R I$ & Minor $(<150)$ & Moderate $(150 \sim 300)$ & High (300 600) & Very high $(>600)$ & & & \\
\hline
\end{tabular}

UP - unpolluted, UMP - unpolluted-moderately polluted, MP - moderately polluted, MSP - moderately to strongly polluted, $\mathrm{SP}$ - strongly polluted, SEP - strong-extremely polluted, EP - extremely polluted.

metal contamination in terrestrial, aquatic, and marine environments, and to quantify heavy metal accumulation, which compares the present status with the background values [27]. $I_{\text {geo }}$ is mathematically expressed as:

$$
I_{g e o}^{n}=\log _{2}\left(C_{n} / k B_{n}\right)
$$

...where $C_{n}$ is the measured concentration of the examined heavy metal $(n)$ in soil or sediment, and $B_{n}$ is the background concentration of elements $n$ and $k$. The background matrix correction factor due to lithogenic effects was considered using a constant of 1.5 . In this study, $B_{n}$, the local background value for $\mathrm{As}, \mathrm{Cr}, \mathrm{Cu}, \mathrm{Ni}, \mathrm{Pb}$, and $\mathrm{Zn}$ was considered as $5.84 \mathrm{mg} \cdot \mathrm{kg}^{-1}, 78.03 \mathrm{mg} \cdot \mathrm{kg}^{-1}, 25.00 \mathrm{mg} \cdot \mathrm{kg}^{-1}, 29.47$ $\mathrm{mg} \cdot \mathrm{kg}^{-1}, 23.88 \mathrm{mg} \cdot \mathrm{kg}^{-1}$, and $69.88 \mathrm{mg} \cdot \mathrm{kg}^{-1}$, respectively [28]. The geoaccumulation index $\left(I_{g e o}\right)$ was distinguished into seven classes by the calculated value [29] (Table 2).

The potential ecological risk index $(R I)$ proposed by Håkanson [30] was used to evaluate the heavy metal contamination from the perspective of sedimentology by considering the potential toxic effects of the heavy metals on exposed organisms [30]. Mathematically, $E_{i}$ and $R I$ are expressed as following (2) and (3), respectively:

$$
\begin{aligned}
& E_{i}=T_{i} \cdot \frac{C_{i}}{C_{0}} \\
& R I=\sum_{i=1}^{n} E_{i}
\end{aligned}
$$

...where $E_{i}$ is the individual coefficient reflecting the potential ecological risk for element $i, T_{i}$ is the toxicity response coefficient for element $i, C_{i}$ is the measured concentration for element $i$, and $C_{0}$ is the the background value for element $i$. In this study, the local background values are the same as $B_{n}$ in formula (1). Ti accounts for both the exposure level and the potential toxic response effect, and has been established as 10 for $\mathrm{As}, 2$ for $\mathrm{Cr}$ and $\mathrm{Ni}, 5$ for $\mathrm{Cu}$ and $\mathrm{Pb}$, and 1 for $\mathrm{Zn}[30]$.

\section{Statistical Analysis}

One-way analysis of variance (ANOVA) and least-significant difference (LSD) analysis were performed to determine if there were significant differences in physicochemi- cal properties and concentrations of heavy metals from soil and sediment. Moreover, Pearson's correlation analysis was used to test the relationship among heavy metals and physiochemical characteristics. All the statistical analyses were performed using SPSS 13.0 for Windows.

\section{Results and Discussion}

\section{Physicochemical Properties}

Compared with soil in situ, water content, organic matter, and total phosphorus of sediment in sediment were significantly high $(\mathrm{p}<0.05)$, while bulk density was low $(p<0.05)$ (Fig. 1). Moreover, there were also no significant differences in water content, $\mathrm{pH}$, bulk density, organic matter, total nitrogen, and total phosphorus between $0-10 \mathrm{~cm}$ and $10-20 \mathrm{~cm}$ from either sediment or soil in the riparian (p>0.05) (Fig. 2).

In most reservoirs, in fact, nutrients in sediment are much higher than in the parent soil [31]. In this study, the results also indicated that organic matter and total phosphorus of sediment were significantly higher than those from soil $(p<0.05)$. Differences in physicochemical properties between soil and sediment can be attributed to formation regime. In the TGR, sediment may be from the following three possible sources: upstream watersheds (e.g. Jinsha, Min, Jialing, and $\mathrm{Wu}$ ), local uplands and catchments, and bank erosion in the riparian zone. The former two types of sources mainly occur in association with storm runoff during the rainy season, while the last source occurs extending the whole hydrologic year due to the occurrence of intensive stream waves trigged by frequent navigation [5]. Soil may be formed in place from rock or in weathered rock and minerals that have been transported from where the original rock occurred. Therefore, nutrients of sediment were richer than soil in situ according to the regime of formation.

\section{Metal Concentration and Contamination Assessment}

Concentrations of $\mathrm{As}, \mathrm{Cu}, \mathrm{Pb}$, and $\mathrm{Zn}$ from sediment were significantly higher than those from soil $(p<0.05)$, but no significant differences in $\mathrm{Cr}$ and $\mathrm{Ni}$ were found $(\mathrm{p}>0.05)$ (Fig. 1). Moreover, there are no obvious differences in concentrations of heavy metals measured between $0-10 \mathrm{~cm}$ and $10-20 \mathrm{~cm}$ in either sediment or soil ( $\mathrm{p}>0.05)$ (Fig. 1). 

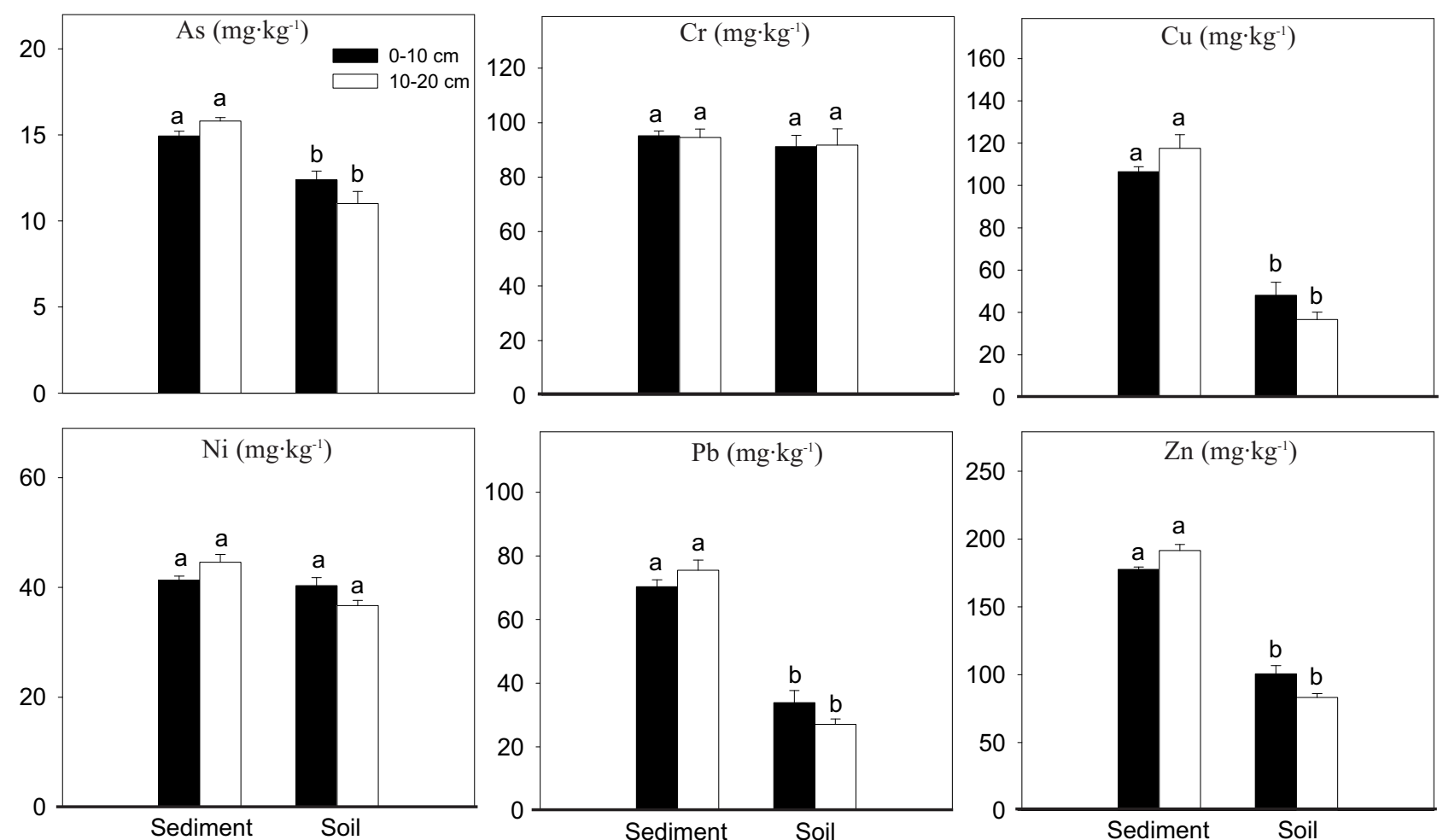

Fig. 1. Concentrations of heavy metals from the sediment and soil in the riparian zone (mean $\pm \mathrm{SE}$ ).

Different letters indicate the statistically significant differences $(\mathrm{p}<0.05)$ between sediment and soil by least-significant difference (LSD) analysis in one-way ANOVA.
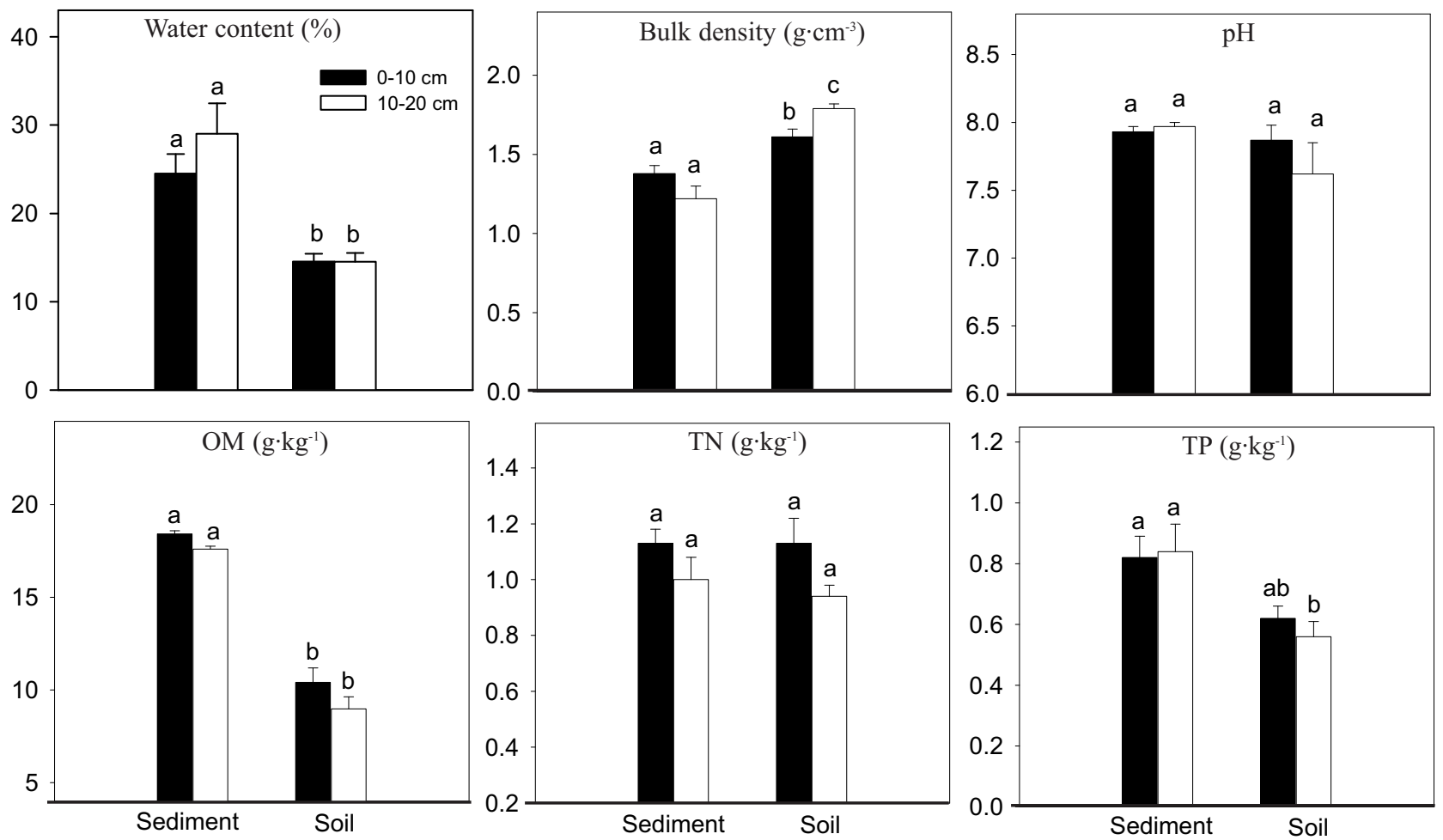

Fig. 2. Physicochemical properties of the sediment and soil in the riparian zone (mean $\pm \mathrm{SE}$ ).

Different letters indicate the statistically significant differences $(\mathrm{p}<0.05)$ between sediment and soil by least-significant difference (LSD) analysis in one-way ANOVA. 
Table 3. Individual and general indices of potential ecological risk.

\begin{tabular}{|c|c|c|c|c|c|c|c|c|c|c|c|c|c|c|c|}
\hline & & \multicolumn{2}{|c|}{ As } & \multicolumn{2}{|c|}{$\mathrm{Cr}$} & \multicolumn{2}{|c|}{$\mathrm{Cu}$} & \multicolumn{2}{|c|}{$\mathrm{Ni}$} & \multicolumn{2}{|c|}{$\mathrm{Pb}$} & \multicolumn{2}{|c|}{$\mathrm{Zn}$} & \multicolumn{2}{|c|}{ RI } \\
\hline & & 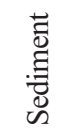 & $\begin{array}{l}\overline{0} \\
\tilde{n}\end{array}$ & 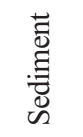 & $\begin{array}{l}\bar{\delta} \\
\mathscr{\leftrightarrow}\end{array}$ & 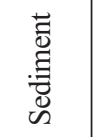 & $\begin{array}{l}\bar{\varnothing} \\
\text { ñ }\end{array}$ & 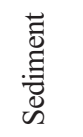 & $\begin{array}{l}\bar{\delta} \\
\mathscr{n}\end{array}$ & 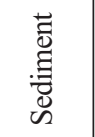 & $\begin{array}{l}\overline{\bar{D}} \\
\text { ñ }\end{array}$ & 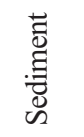 & $\begin{array}{l}\overline{\bar{D}} \\
\text { ñ }\end{array}$ & 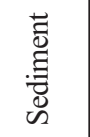 & $\begin{array}{l}\bar{D} \\
\text { ñ }\end{array}$ \\
\hline \multirow{2}{*}{ Polluted level } & $I_{g e o}$ & 0.78 & 0.41 & -0.29 & -0.37 & 1.51 & 0.12 & -0.02 & -0.15 & 1.03 & -0.29 & 0.76 & -0.22 & - & - \\
\hline & Grade & UMP & UMP & UP & UP & MP & UMP & UP & UP & MP & UP & UMP & UP & - & - \\
\hline \multirow{2}{*}{$\begin{array}{c}\text { Potential } \\
\text { ecological risk }\end{array}$} & $E_{i} / R I$ & 26.34 & 20.03 & 2.43 & 2.34 & 22.41 & 8.46 & 2.92 & 2.61 & 15.27 & 6.37 & 2.64 & 1.31 & 72.00 & 41.14 \\
\hline & Grade & \multicolumn{14}{|c|}{ Minor } \\
\hline
\end{tabular}

UP - unpolluted, UMP - unpolluted-moderately polluted, MP - moderately polluted

Table 4. Correlation matrix among physicochemical properties and concentrations of heavy metals from sediment and soil.

\begin{tabular}{|c|c|c|c|c|c|c|c|c|c|c|c|c|}
\hline & $\mathrm{WC}$ & $\mathrm{BD}$ & $\mathrm{pH}$ & $\mathrm{OM}$ & $\mathrm{TN}$ & $\mathrm{TP}$ & $\mathrm{As}$ & $\mathrm{Cr}$ & $\mathrm{Cu}$ & $\mathrm{Ni}$ & $\mathrm{Pb}$ & $\mathrm{Zn}$ \\
\hline $\mathrm{WC}$ & 1 & & & & & & & & & & \\
\hline $\mathrm{BD}$ & $-0.838^{* *}$ & 1 & & & & & & & & & \\
\hline $\mathrm{pH}$ & 0.322 & -0.346 & 1 & & & & & & & & & \\
\hline $\mathrm{OM}$ & $0.866^{* *}$ & $-0.867^{* *}$ & 0.269 & 1 & & & & & & & & \\
\hline $\mathrm{TN}$ & 0.073 & -0.296 & 0.046 & 0.183 & 1 & & & & & & & \\
\hline $\mathrm{TP}$ & $0.464^{*}$ & $-0.427^{*}$ & $0.408^{*}$ & $0.581^{* *}$ & -0.249 & 1 & & & & & & \\
\hline $\mathrm{As}$ & $0.805^{* *}$ & $-0.797^{* *}$ & 0.155 & $0.746^{* *}$ & 0.299 & 0.303 & 1 & & & & & \\
\hline $\mathrm{Cr}$ & 0.108 & 0.025 & -0.343 & 0.173 & -0.294 & 0.041 & $0.399^{*}$ & 1 & & & & \\
\hline $\mathrm{Cu}$ & $0.879^{* *}$ & $-0.838^{* *}$ & 0.334 & $0.880^{* *}$ & 0.074 & $0.545^{* *}$ & $0.842^{* *}$ & 0.228 & 1 & & & \\
\hline $\mathrm{Ni}$ & $0.456^{*}$ & $-0.514^{*}$ & 0.200 & $0.400^{*}$ & 0.351 & 0.199 & $0.733^{* *}$ & $0.384^{*}$ & $0.449^{*}$ & & 1 & \\
\hline $\mathrm{Pb}$ & $0.917^{* *}$ & $-0.849^{* *}$ & 0.354 & $0.904^{* *}$ & 0.103 & $0.539^{* *}$ & $0.874^{* *}$ & 0.208 & $0.947^{* *}$ & $0.494^{* *}$ & 1 & 1 \\
\hline $\mathrm{Zn}$ & $0.882^{* *}$ & $-0.836^{* *}$ & $0.374^{*}$ & $0.893^{* *}$ & 0.089 & 0.603 & $0.856^{* *}$ & 0.254 & $0.968^{* *}$ & $0.550^{* *}$ & $0.967^{* *}$ & 1 \\
\hline
\end{tabular}

$\mathrm{WC}$ - water content, $\mathrm{BD}$ - bulk density, $\mathrm{OM}$ - organic matter, $\mathrm{TN}$ - total nitrogen, $\mathrm{TP}$ - total phosphorus.

$*$ at 0.05 significance level, $* *$ at 0.01 significance level.

The $I_{g e o}$ indicated that sediment was unpolluted by $\mathrm{Cr}$ and $\mathrm{Ni}$; unpolluted-moderately polluted by $\mathrm{As}$ and $\mathrm{Zn}$; and moderately polluted by $\mathrm{Cu}$ and $\mathrm{Pb}$; while soil was unpolluted by $\mathrm{Cr}, \mathrm{Ni}, \mathrm{Pb}$, and $\mathrm{Zn}$; and unpolluted-moderately polluted by $\mathrm{As}$ and $\mathrm{Cu}$ (Table 3). The $E_{i}$ values of heavy metals decreased in the order of $\mathrm{As}>\mathrm{Cu}>\mathrm{Pb}>\mathrm{Ni}>\mathrm{Zn}>\mathrm{Cr}$ for sediment, and the order is $\mathrm{As}>\mathrm{Cu}>\mathrm{Pb}>\mathrm{Ni}>\mathrm{Cr}>\mathrm{Zn}$ for soil. All of $E_{i}$ values were less than 40, suggesting that individual heavy metal in sediment and soil was a potentially minor risk (Table 3 ). Moreover, $R I$ of both soil and sediment are less than 150, indicating that heavy metals as a whole are a potentially minor risk (Table 3 ).

In this study, concentrations of heavy metals in sediment were significantly higher than those in the riparian soil (Table 3). The excessive contents of heavy metals in sediment compared with soil should be partially ascribed to external input of contaminated sediment produced from upstream anthropogenic sources, including point sources and diffuse sources. The former was related to industrial effluents, domestic sewage, and waste disposal, while the last was related to urban runoff, atmospheric deposition, and agricultural solids (e.g. fertilizer, pesticides, and herbicides) $[16,17]$. On the other hand, correlation analysis showed that heavy metals have significantly correlated each other except for $\mathrm{Cr}$ (Table 4), suggesting that they might have similar pollution sources $[32,33]$. Moreover, the nutrient is significantly positively related to heavy metals (except Cr) (Table 4), suggesting that enrichment of the nutrient may be a reason for richer heavy metals in sediment of the riparian zone in the TGR.

\section{Conclusions}

Compared with soil in situ, water content, organic matter, total phosphorus, heavy metals ( $\mathrm{As}, \mathrm{Cu}, \mathrm{Pb}$, and $\mathrm{Zn}$ ) of sediment were significantly high, but bulk density was low. $I_{\text {geo }}$ indicated that soil was contaminated by $\mathrm{As}$ and $\mathrm{Cu}$, 
while sediment was polluted by $\mathrm{As}, \mathrm{Cu}, \mathrm{Pb}$, and $\mathrm{Zn}$. Moreover, correlation analysis showed that heavy metals had significant positive correlation with each other except for $\mathrm{Cr}$, suggesting that they maybe have similar pollution sources. Enrichment of nutrients and heavy metals in sediment of the riparian zone are probably of formation regime and human activities related to pollutant emission, and could pose risks to the environment and human health. To reduce the effect of sediment and soil of the TGR riparian zone, enhanced controls of soil erosion and pollution treatment in the upper stream of the Yangtze River and the TGR area are recommended.

\section{Acknowledgements}

This study was financially supported by the National Key Science and Technology Project for Water Environmental Pollution Control (2012ZX07104-003) and the Natural Science Foundation Project of CQ CSTC (cstc2012jjA00008, cstc2012jjB20003).

\section{References}

1. YANG S.L., ZHANG J. DAI S.B., XU X.J. Effect of deposition and erosion within the main river channel and large lakes on sediment delivery to the estuary of the Yangtze River. J. Geophys. Res. 112, 2003, 2007.

2. XU K.H., MILLIMAN J. D. Seasonal variations of sediment discharge from the Yangtze River before and after impoundment of the Three Gorges Dam. Geomorphology 104, 276, 2009.

3. HU B.Q., YANG Z.S., WANG H.J., SUN X.X., BI, N.S. Sedimentation in the Three Gorges Dam and its impact on the sediment flux from the Changjiang (Yangtze River), China. Hydrol. Earth Syst. Sci. Discuss. 6, 5177, 2009.

4. YUAN J., XU Q.X., TONG H. Study of sediment deposition in region of Three Gorges reservoir after its impoundment. J. Hydroelectr. Eng. 32, 139, 2013.

5. TANG Q., BAO Y.H., HE X.B., ZHOU H.D., CAO Z.J., GAO P., ZHONG R.H., HU Y.H., ZHANG X.B. Sedimentation and associated trace metal enrichment in the riparian zone of the Three Gorges Reservoir, China. Sci. Total Environ. 479-480, 258, 2014.

6. HU B.G., YANG Z.S., WANG H.J., SUN X.X., BI N.S., LI G.G. Sedimentation in the Three Gorges Dam and the future trend of Changjiang (Yangtze River) sediment flux to the sea. Hydrol. Earth Syst. Sci. 13, 2253, 2009.

7. GONZÁLEZ-MACÍAS C., SCHIFTER I., LLUCH-COTA D.B., MENDEZ-RODIGUEZ L., HERNÄNDEZVÄZQUEZ S. Distribution, enrichment and accumulation of heavy metals in coastal sediments of Salina Cruz Bay, Mexico. Environ. Monit. Assess. 118, 211, 2006.

8. LI S.Y., ZHANG Q.F. Risk assessment and seasonal variations of dissolved trace elements and heavy metals in the Upper Han River, China. J. Hazard. Mater. 181, 1050, 2010.

9. TAM N.F.Y., WONG Y.S. Spatial variation of heavy metals in surface sediments of HongKong mangrove swamps. Environ. Pollut. 110, 195, 2000.

10. SAINT-LAURENT D., HÄHNI M., ST-LAURENT J., BARIL F. Comparative Assessment of Soil Contamination by Lead and Heavy Metals in Riparian and Agricultural Areas (Southern Québec, Canada), Int. J. Environ. Res. Public Health 7, 3100, 2010.

11. ZHANG H.G., CUI B.S., RONG X., XIAO R. Heavy metals in water, soils and plants in riparian wetlands in the Pearl River Estuary, South China. Procedia Environ. Sci. 2, 1344, 2010.

12. BAIN D.J., YESILONIS I.D., POUYAT R.V. Metal concentrations in urban riparian sediments along an urbanization gradient. Biogeochemistry. 107, 67, 2102.

13. JACOB D.L., YELLICK A.H., KISSON T.K.L., ASGARY A., WIJEYARANTNE D.N., SAINI-EIDUKAT B., OTTE M.L. Cadmium and associated metals in soils and sediments of wetlands across the Northern Plains, USA. Environ. Pollut. 178, 211, 2013.

14. FU C., GUO J.S., PAN J., QI J.S., ZHOU W.S. Potential Ecological Risk Assessment of Heavy Metal Pollution in Sediments of the Yangtze River within the Wanzhou Section, China. Biol. Trace Elem. Res. 129, 270, 2009.

15. ZHANG Y.M., LIU H., WEI S.Q., TAO J., LIU L.Q., LIU Y., GONG M.Y. Investigation and assessment of heavy metal pollution from various vertical heights in water flooding fluctuation zone of Three Gorges Reservoir Areas. Chinese Agri. Sci. Bull. 27, 317, 2012 [In Chinese with English Abstract].

16. YE C., LI S.Y., ZHANG Y.L., ZHANG Q.F. Assessing soil heavy metal pollution in the water-level-fluctuation zone of the Three Gorges Reservoir, China. J. Hazard Mater. 191, 366, 2011.

17. WANG Y.C., LEI B., YANG S.M., ZHANG S. Concentrations and pollution assessment of soil heavy metals at different water-level altitudes in the draw-down area of the Three Gorges Reservoir. Environ. Sci. 33, 612, 2012 [In Chinese with English Abstract].

18. AO L., LEI B., WANG Y.C., ZHANG S. Sediment Risk assessment and heavy metal source analysis in typical country water level fluctuated zone (WLFZ) of the Three Gorges. Environ. Sci. 35, 79, 2014 [In Chinese with English Abstract].

19. LEI BO., YANG C.H., YANG S.M., ZHANG S. GIS-based division of ecological types and their characteristic of waterlevel-fluctuating zone in the Three Gorges Reservoir of Yangtze River. Chinese J. Ecol. 31, 2082, 2012 [In Chinese with English Abstract].

20. WANG Y.C., LEI B., ZHANG S. Differences in vegetation and soil characteristics at different water-level altitudes in the drawdown area of Three Gorges Reservoir. J. Lake Sci. 24, 206, 2012 [In Chinese with English Abstract].

21. BELYAEV V.R., WALLBRINK P.J., GOLOSOV V.N., MURRAY A.S., SIDORCHUK A.Y. A comparison of methods for evaluating soil redistribution in the severely eroded Stavropol region, southern European Russia. Gemoprhology. 65, 173, 2005.

22. RICHARDS L.A. Diagnosis and Improvement of Saline and Alkali Soils. In U.S. Department of Agriculture Handbook, Washington D.C, USA. 60, 160, 1954.

23. LU R.K. Soil Agrochemical Analysis Methods, China Agriculture Science and Technology Press; Beijing, pp. 102129, 1999 [In Chinese with English Abstract].

24. Environmental Protection Agency. http://www.epa.gov/sw846/pdfs/3050b.pdf. 1996.

25. YE C., ZHANG K.R., DENG Q., ZHANG Q.F. Plant communities in relation to 'flooding and soil characteristics in the water level fluctuation zone of the Three Gorges Reservoir, China. Environ. Sci. Pollut. Res. 20, 1794, 2013. 
26. MULLER G. Index of geoaccumulation in sediments of the Rhine River. Geojournal. 2, 108, 1979.

27. ROUT S., KUMER A., SARKAR P.K., MINSHRA M.K., RAVI P.M. Application of Chemometric methods for assessment of heavy metal pollution and source apportionment in Riparian zone soil of Ulhas River estuary, India. Int. J. Environ. Sci. 3, 1485, 2013.

28. TANG J., ZHOU Y.P., WANG L. Background value of soil heavy metal in the Three Gorges Reservoir District. Chinese J. Eco-Agric. 16, 848, 2008.

29. MÜLLER G. The heavy metal pollution of the sediments of the Neckars River and its tributaries: an inventory. Chemic. Newspaper. 105, 157, 1981 [In German].

30. HÅKANSON L. An ecological risk index for aquatic pollution control: a sedimentological approach. Water Res. 14, 975, 1980 .
31. FONSECA R., BARRIGA F.J.A.S., FYFE W. Dam reservoir sediments as fertilizers and artificial soils. Case studies from Portugal and Brazil. In Proceedings, water and soil environments, biological and geological perspectives; Tazaki K.; International symposium of the Kanazawa University $21^{\text {st }}$ century COE Program. Kanazawa, Japan, pp. 55-62, 2003.

32. JIANG M., ZENG G.M., ZHANG C., MA X.Y., CHENG M., ZHANG J.C., LIU L.H., YU Q., HU L.P., LIU L.F. Assessment of heavy metal contamination in the surrounding soils and surface sediments in Xiawanggang river, Qingshuitang District. PloS ONE. 8, 71, 2014.

33. TANG X.J., HASHMI M.Z., LONG D.Y., CHEN L.T., KHAN M.I., SHEN C.F. Influence of heavy metals and PCBs pollution on the enzyme activity and microbial community of paddy soils around an e-waste recycling workshop. Int. J. Environ. Res. Public Health. 11, 3118, 2014. 
